\title{
Knowing the Constitutional Law: A Lexicon and Epistemology on Korean Scholarship
}

\author{
Kiyoung Kim ${ }^{\circledR}$, Shahin Borhanian \\ Department of Prelaw, College of Social Science, Chosun University, Gwang-ju, South Korea \\ Email: kiyoungkim@chosun.ac.kr, hsi1844@chosun.ac.kr
}

How to cite this paper: Kim, K., \& Borhanian, S. (2019). Knowing the Constitutional Law: A Lexicon and Epistemology on Korean Scholarship. Beijing Law Review, 10, 949-970.

https://doi.org/10.4236/blr.2019.104051

Received: August 1, 2019

Accepted: September 3, 2019

Published: September 6, 2019

Copyright (c) 2019 by author(s) and Scientific Research Publishing Inc. This work is licensed under the Creative Commons Attribution International License (CC BY 4.0).

http://creativecommons.org/licenses/by/4.0/ (c) (i) Open Access

\begin{abstract}
The paper attempts to deal with the element of generic section within the Korean constitutional law. Although the translation of Constitution or case laws of Korea is available for the English-speaking scholarship, the typology and epistemology elaborated by legal scholars through texts or classroom have been entirely discrete and do not appear in academia globally. An earlier generation of scholars who had in mind to disseminate the basics of Korean law plays their part, and yet their work is outdated and needs to be amended such that foreign lawyers and academics can more readily be exposed to Korean law updated for contemporary discourse. The law is a social product and its language often has a repercussion with a great import concerning the court matters and legal scholarship as is apparent from the legal interpretation and work of annotators. An abysmal confusion inherent within the national jurisprudence surrounding its linguistic elements may be comparable to the chaos of the Babel tower when viewed within global legal scholarship. On the other hand, Korea has long been one of the rising states in terms of the national economy and diplomatic prestige. Under this backdrop, it became embarrassingly clear that an English version of legal scholarship on the basics of Korean law is necessary for peers working in jurisprudence and other interested scholars. This project may require an extensive period of time and energy along with other numerous areas of concern in Korean law. While the pioneers may already have initiated this kind of endeavor as mentioned, this engagement will hopefully aid in reworking the old versions of introduction works on Korean law. In this paper, I introduced a general overview of constitutional law over seven sections and entailed a reflexivity related with the introduction.
\end{abstract}

\section{Keywords}

Epistemology, Korean Constitutionalism, Human Right, Nationality Clause, 
Partisan Clause, Public Officer, Public Election, Territoriality Clause

\section{Introduction}

\subsection{Dual Facet on Epistemology}

Constitutional law in Korea is the supreme law of the land and functions to protect fundamental rights and organize the branches of government. Since the law prescribes public order and the governmental system, it is classified into the category of public law, which differs from private laws regulating the legal relationship among citizens (Huh, 2018; Kim, 2013; Kweon, 2010). Constitutional law is functionally intertwined with administrative law, which ordains the substantive rights and procedures for public administration. The domains of the two legal frameworks can be distinguished in that administrative law is technical, realistic and specific to dispose of disputes against government action or inaction whilst constitutional law is prescriptive, idealistic and abstract to deal with the challenge and universality of politics and public life. Because the nature of constitutional law involves the dual facets of political facts and basic normative order, its epistemology (Habermas, 2007; Foucault, Faubion, \& Hurley, 1998) can be shaped in two dimensions, i.e., the constitution as a sociological concept or as defined by legal scholarship.

According to Lassale (1987), constitutional law reflects the political relationship in its very nature and should be viewed in terms of its interaction with the reality of rule and governance. As Smend (1928) informs, the constitution serves to integrate the public lives in a specific polity and provides the principle and norms for a variety of interest groups to act or proceed toward a political unity. C. Schmitt also advises his theory of political determinism to explain the nature of constitutional law. He argues that constitutional law is nothing but the will of a sovereign people in arranging for the nature and forms of political unity (Balakrishnan \& Schmitt, 2000).

The constitutional law from normative understanding is distinct in that it confronts, regulates the political reality and provides a legal yardstick to measure public and political life in the nation. W. Kagi describes it as the framework of national supreme laws (Gozzi, 2007) while K. Stern defines it as supreme law establishing the principles that create the governmental system and public values (Borowski, 2003; Engel, 2001).

\subsection{Classic and Modern Constitutionalism}

In its classic epistemology, the constitutional function is limited to the prescription of the national order concerning its basic legal system and framework, as well as the supreme organs of government and their functions. The notion is universal and omnipresent through history whenever the nation has existed, notwithstanding variations in time, the particular nations or the nature of their 
legal communities (Caenegem, Caenegem, \& Johnston, 1995; Pomeroy, 1888; Ray, 2019).

A constitution formulated through modern civilian hegemony includes norms of revolutionary product that add new protective principles and bills of rights, including separation of powers and other safeguards of human rights (Reus-Smit, 2001; Hopton, 1978). These new constitutional forms and functions can be ascertained eloquently in Art. 16, of the 1789 French Declaration of $\mathrm{Hu}$ man Rights, namely, that "there is no constitution in society if the protection of human rights and separation of powers are not instated." The constitution in this sense restrains a tyranny or dictatorship of monarchy and promotes a safeguard of constitutional rights (Glendon, 1997). Five principles are pivotal in this province of constitutionalism, encompassing popular sovereignty, bills of rights, separation of powers, parliamentary systems, rule of law via enacted statutes, and a written constitution.

The constitution in a welfare or provisional state (Rosas \& Armati, 2018) is made distinct from its earlier forms in that the language begins to be active and provisional beyond merely equal protection with respect to negative liberties It rather stresses positive liberties and substantial justice, while largely endorsing the state's intervention into the market and offers a more flexible understanding of property rights. The Weimar constitution of 1919 is considered an early example of a constitution in this sense (Hartmann, 2003). The contemporary welfare constitution entails several elements i.e. 1) substantiation of popular sovereignty, 2) a set of social rights, 3) rule of law for substantial justice, 4) equal protection in positive liberties, 5) new frameworks for the separation of powers principle, 6) social order in the market, 7) enhanced normative control, 8) the administrative state, and 9) the principle of international peace.

\section{Classification and Categories}

\subsection{Traditional Tools to Classification}

In view of its forms, the constitution has been classed into two categories, including written and unwritten forms (Barendt, 1998). A written constitution refers to the formal documentary form of constitution enacted in accordance with the established procedural requirement. The constitution of State of Virginia in 1776 is considered a first written constitution in world history (Selby, 1976). An unwritten constitution refers to the supreme laws of the nation ascertained and enforced through constitutional history and governmental practice. It has no unitary code on some point of historical resolution or revolution. The constitutions of the United Kingdom, New Zealand, Canada, and Israel fall within the latter category, whilst a vast of number of nations in modern democracies have formerly instituted written constitutions. Written constitutionalism had been encouraged under the influence of natural law and social contract theories, and has served to dismantle ancient regimes and reacted to produce the socio-political reorientation of nations. It is clearer and more convenient to found 
new institutions and social order in written form. This nature of written constitutionalism is the reason that has fueled its flourishing across a wide grouping of nations in global jurisdictions.

Constitutions are classed into two other types, namely, hard and soft constitutions (Huh, 2018; Kim, 2013; Kweon, 2010). This classification relies on the weight of the revisional requirements and the specifics of revision procedure. A soft constitution is noted when the requirements and procedures of revision are equivalent to those of congressional acts. A hard constitution is found when the constitution imposes a weightier requirement and more complex procedure to revise the constitution in effect. Constitutions of the United Kingdom, Sadinia Kingdom in Italy, and post-1947 New Zealand fall within the soft types. The remaining majority of constitutions worldwide are vastly hard in terms of their revision methods.

The constitutions can be sorted to rely on whom the constitutional sovereignty lies and how the constitution is established, which includes four categories, including 1) constitution of a monarch, 2) a civil constitution, 3) constitution as concession, and 4) constitution on assent or admission (Barendt, 1998; Caldwell, 1997). The constitution of a monarch exists when the sovereign power that establishes or revises the constitution is the King or monarch, which corroborates with the classic thought on the divinity of monarchy. This type of constitution appears in history as illustrated in the French constitution resurrected after the Thermidorian reaction, with reinstatement of Louis $18^{\text {th }}$ in 1814 , the German constitution in early 19 century, as well as Meiji constitution in 1889. The civil constitution is found when the constitution is established directly by the plebiscite or popular vote of a nation or by a constitutional congress, often specially convened for that purpose. A vast group of republican democracies around world can be viewed to meet this category, as well as the respective states of the United States (Kim, 1992). The constitution on concession is established on the condition that the monarch and representatives of people come to agree, compromise and eventually concede on its nature and key elements. Most notable example would be French constitution in 1830. The constitution on assent and admission is created when more than two states agree to formulate one national government, often called as federal nation. The 1867 constitution between Austria and Hungary, Bismark constitution in 1871, and CIS in 1992 Russia fall within this category. Since the US constitution requires two stages of constitutional establishment or revision, say, state legislature and special congress, the nature is viewed as complex between the second and fourth types.

\subsection{Classification on K. Lowenstein's Viewpoint}

Lowenstein (1976) proposed an interesting theoretical classification of constitutions, focused on the normativity of constitutions and their existential realities. He illustrated three categories of constitutions, namely, normative, nominal, and ornamental ones. The normative constitution refers to the supreme law origi- 
nating the democratic element to fully effectuate such basic norms of the nation that realistically serve modern constitutionalism, for example, protection of human rights and civil liberties. In this category of constitutions, the normative profile corresponds with the constitutional facts and reality of national practice. The governments of fully developed democracies are viewed to practice this type of constitutionalism. A constitution that is nominal in nature is futilely idealistic in its content and prescriptions, and the social conditions or governmental practice are unfit to realize the stated goals and requirements of the constitution. The constitutions of underdeveloped nations may often fall within this category. Finally, an ornamental constitution indicates that the polity is not created to serve the end of regulating the nation or community, but with the aim to propagandize its existence to foreign nations or justify the ruler's reign or dictatorship of a tyrant. The constitutions of past communist nations and the tyrannies of underdeveloped states may appertain to this category.

\section{Foundation and Reform of Constitution}

\subsection{Founding of Constitution}

A founding constitution arises from the substantive viewpoint that a sovereign power legitimate to shape the nature and character of political union creates the supreme law as normative and binding (Reynolds, 2002). It also occurs in view of formalistic viewpoint when the constitution as a supreme code of nation comes to be formulated and endorsed (Bellah, 1978; Eidsmoe, 1987). The power to act on constitutional founding often occurs in a sort of national congress elected through the popular vote on democratic principle. Given that popular sovereignty has been deeply imbedded in modern times, it is generally agreed that the people in an indiscriminate sense are the only body of persons to legitimately found the supreme law of the land in any modern nation (LaCroix, 2015; Reynolds, 2002).

\subsection{Reform of Constitution}

The reform of constitution is defined as an act to eliminate, revise, or add the articles intentionally with the intent to reform the language and provisions within it (Huh, 2018; Kim, 2013; Kweon, 2010). It is neither permissible to violate the procedural requirement of revision nor to derogate the fundamental elements, which differs from constitutional founding because of its original and creative nature of incident. The revision of a constitution is necessary, but restrictive against the normal congressional acts. It needs to be called on several conditions, say, in case where the people view it is necessary 1) to safeguard the normative or persuasive power of the existing constitution in order to maintain its binding effect as a real norm, 2) to prevent the destruction of the constitution stemming from an excessively stern system of revision or the overly-permissive revisionism by a political power that is dissatisfied with the constitution, 3) to allow, as a matter of constitutional policy, the chance for participation of subsequent polit- 
ical parties or groups through the constitutional formulation. The style of revision has two traditions. Amendments occur when the reform is made with addition of new articles, which are styled as amendments. Revisions generally refer to an incident when the language and provision of the constitution is changed through elimination, rewording or inserting (White, 1951). The methods and procedures of constitutional reform vary depending on the policy of specific constitutional states. Generally three traditions exist; 1) a weightier process is imposed although only a congressional resolution is technically necessary to legitimate reform as illustrated in Germany, Sweden, and the first republic of south Korea, 2) the process requires additional steps for plebiscite endorsement 3) a process requires a certain level of state consent as uniquely so for federal systems 4) a special committee for constitutional reform needs to be convened to propose a revision or amendment 5) a process requires approval by a special organ.

One of the hottest issues surrounding constitutional scholarship underlies the difficult and sophisticated question pertaining to whether constitutional reform shall be deemed legitimate regardless of theoretical limits or restrains (Graves, 1960). In other words, is there constitutional provision or language that is, by definition, not susceptible to revision or contradiction through subsequent constitutional reform? The matter is not disputable when the constitution itself clearly describes the limits and restrains of revision in its own words. Scholars are not in agreement, and two thoughts are currently standing. The proponents of limitation argue that the act of reforming a constitution is impliedly and theoretically constrained and that revision concerning certain mandates or provisions is of no effect even if it faithfully complies with the established procedure. The opposing view that calls for boundless reform, rejects the foregoing argument and proposes that reform always takes effect when it occurs through the established procedure for revision. A plethora of scholars support the first view and critique the second because the latter thought fails to recognize the inherent legal incidents associated with the gravity of the respective provisions, which is viewed as stressing the face of the document and the written form akin to the evil current of legal positivism. The criticism also points to the failure of formalism, which defaces substantial justice, calling instead for reason and the authority of natural law. The second view, in turn, can possibly falter by deviating from any potential services provided by permissive constitutional reform. In sum, however, scholars dominantly agree on the first view that there exists a certain inherent part of constitution that may never be derogated through constitutional reform. In our next concern, we need to defend the founded or reformed constitution against the enemy of state, for example, tyranny or communist dictatorship as well as unconstitutional act of government

\section{Defense of Constitutionalism}

The defense of constitutionalism refers to a system or institution that functions 
to preserve the finality and effectiveness of a constitution as the supreme law of the land. It functions to prevent in advance, or correct post-incidentally, from any ingression or transgression that destroys its normative power and public role (Rossiter, 2017). A constitutional founding is predicated on the premise that it is normative to effect as a law. It is, therefore, logically true that the constitution has to be defended against an enemy or threat to its normative foundations. The defense of constitutionalism in this sense preserves the identity and keeps the constitution safe against inward or exterior threats as well as harmful chaos brought about by vertical disorder. Constitutional defense in Korea encompasses several categories related to the thread of constitutional classification. A notable thread is whether the normative power of the constitution is politically or judicially safeguarded (Cepeda, 1998). A second thread attempts to determine whether it is explicitly ensured or impliedly ensured. Constitutional defense also can be classed by whether it is substantive or procedural. Another framework views whether the defense is guaranteed through normal constitutional conditions or emergent and special procedures. The conundrum of determining the final constitutional guardian has long plagued politicians and scholars, which properly characterizes the apex of nationalism around 1930's. C Schmitt emphasized the role of the presidency as the bulwark of a constitution, whilst H. Kelsen highlighted the responsibility of all three branches, president, congress, and constitutional court, balanced equally in view of the normative and functional constitutionalism of checks and balances. Contemporary scholars dominantly believe that people are or should be sovereign as the final guardians to insure the effectiveness of an essential constitutional system or institution against derogation or threat.

\subsection{Types of Constitutional Defense}

There are generally four types of constitutional defense systems, as described below (Huh, 2018; Kim, 2013; Kweon, 2010).

The preliminary or preventive system includes, "democratic partisan system, assistance from the international politics and pressure group, control by the electorate, respect of people for constitutionalism, express proclamations for the supremacy of the constitution, separation of powers principle, limits and restrains of constitutional reform, neutrality of public officers, party clause on provisions and requirements for a semi-presidential system, etc."

Several traditions fall within the post-incidental or corrective system, which cover "the judicial review of unconstitutional acts, impeachment clause, party clause mandating dissolution of the political clause as well as the ethics and responsibility of public offices. It restores from the destructive effect post-incidentally by ousting or negating it."

The third defense on Korean constitutionalism is indebted to the enumerated constitutional powers in a national emergency (ECPNE). ECPNE is referred to when the government seeks a temporal exercise of constitutional power to meet a national crisis or emergency for public security and order. The constitution 
specifically authorizes the power during war, civil revolt, and other disruptions of the national order with a broad catch-all clause, namely, "other situations imminent to threaten the function and peace of the nation or constitutional order," as a permissive condition to invoke the emergency power of government. This type of institutional power also plays its part in the defense of democratic constitutionalism. The historical application of constitutional emergency powers in Korea had been varied with respect to the institution of the ECPNA, although their character, at least on its express terms, has appeared civilian based on popular consent for the democratic form of government.

Civil disobedience, as a type of constitutional discourse, is viewed as the final resort of the people in expressing their privilege as sovereigns, to resist government officers or organs to protect the constitutional order and rule of law. The right often is implied and can be inferred without the express grounds in the constitutional language. It can be claimed only if no institutions or process to remedy a trespass or encroachment of governmental branches are available within the positive law (Arendt, 1972). The Korean constitutional court (KCC) also highlighted and reified the principle that "civil disobedience is the right to resist the government that is impliedly enshrined within modern constitutionalism 1) in case of such grave trespasses or encroachment by the governmental branches upon the constitutional ideals, principles, and requirements 2) that are equivalent to the negation of the rule of modern constitutionalism 3) when no other alternative ways are available to remedy such evil 4) in order for the people to safeguard their liberties and rights. People are obliged to respect the government and its administration in generic terms. This is even generally true when the government exercises its power illegally or in impermissible ways. In the normal case when the government acts wrongly, the one wronged is required to seek redress through the due process of law or a legal remedy from loss or injury arising from such wrongful action or inaction. The administrative grievance, complaint, suit, judicial review against unconstitutional acts or orders, or an impeachment could be available to redress the wrongs committed by most exemplary institutions in the constitution. People also are privileged to correct errors politically through elections or disclosure by the press. Once those legal remedies or political resolutions in opposition to the wrongs of government are exhausted, leaving no other alternative, civil disobedience has been authorized as a matter of constitutional theory. The theory serves to respond to the grave question, "Are people disentitled to a remedy, and left only to obey a wrongful governmental act, regardless of whether the individuals officer or organ's actions are arbitrary and undoubtedly transgress the principles of constitutional justice?" In other words, "Are they privileged to exercise their rights as persons or assemblies in order to restore their privileges and protect the constitutional order?" Concerning the right to civil obedience, the constitutional policy in various global jurisdictions diverges surrounding the statutory or case laws and epistemology of its elements. While it is often implied, express language of constitutions is no less seldom, but with differences on its preconditions as a right or 
claim. The Korean constitution lacks any express provisions nor vests it as a constitutional right. Scholars generally agree that the right to civil disobedience is one of the implied natural rights.

\subsection{Emergency Power in Korea}

The constitutional practice on ECPNE in Korea can be made distinct from other traditions, such as in the US and UK, because it includes an express clause limiting an interpretive challenge and preventing judicial law-making in this area of concern. The first constitution articulated three sets of emergency power in a small grouping, what are called emergent presidential orders (EPO), emergent fiscal presidential dispositions (EFPD), and militia orders. Due to criticism and public resentment, the EPO was displaced in the second constitution whilst EFPD, emergent fiscal presidential order (EFPO) and militia orders were made subject to checks and balances to prevent their abusive and tyrannical use. The third constitution restored EPO and enacted the Special Act for National Security and Protection. The act authorized enormous power, potentially trespassing the normal order of constitutional democracy. The fourth constitution reinforced ECPNE and stipulated a strong role for the presidency to meet national emergencies. The power of the president in emergent disposition enlarges the scope of possible dictatorship by forestalling constitutional rights and functions along with the power to call out the militia. The fifth constitution, reflecting the national desire, ameliorated the regime of ECPNE. The emergency power was profiled in a lower constitutional language, whilst the checks and balances mechanisms were ensured through express provisions. The sixth and standing constitution replicated ENCPE on the third case, which constitutionalized EPO, emergent fiscal economic presidential order (EFEPO), and militia orders.

\section{People and National}

\subsection{Requirement to Nationality}

A national refers to an individual affiliated with the nation, who are obliged to respect the government and its administration (Barak-Erez, 2008). The act to circumscribe the scope of national is called "Act on Nationality." Art. 2 Cl. 2 in the Constitution mandates that the requirements for nationality be determined through the acts of Congress. On this mandate, the Congress stipulates a number of articles to define a national, as well as requirements to obtain the status as a national and suffer its loss. Legislative precedents across nations often adopt either of two prevailing traditions when they afford the nationality, one being the territory of birth, or incidence of nationality by pedigree. In other words, a new life on birth may obtain the status by following the nationality of his or her parents or nation of birth place. The first tradition is being practiced by Germany, Australia, Swiss, Japan, and South Korea. The second case is found across the jurisdictions, such as United States, United Kingdom, and Latin American countries. Accordingly, , the alternative post-birth acquisition of nationality oc- 
curs in several occasions of legal incidents, such as marriage, interest and registration to acquire, acquiescence by parents based on family law, restoration, and coincidental acquisition. The act also mandates a loss of nationality when adopted by foreign parents, when voluntarily acquiring a nationality of a foreign nation, or by expressing an intent to relinquish-as an individual of dual nationality-to renounce Korean nationality upon a filing with the ministry of justice. An individual is obliged to alienate his rights-for those entitled to only exclusive nationality-within three years of the year of nationality loss. Upon a lapse on this statutory period, the right automatically ceases. Art. $2 \mathrm{Cl} .2$ of constitution also provides that the government is constitutionally mandated to protect nationals overseas.

\subsection{Nationals on Constitutional Purpose}

Jelinek, a German legal philosopher and proponent of "nation sovereignty," recognized four classes of constitutional status for the nationals based on modern constitutionalism, namely, 1) passive status or subjects to be ruled, 2) active status or participants to rule, 3) positive status or humans on positive liberty, 4) negative status or humans on negative liberty. Scholars generically perceive: 1) nationals as being sovereign, 2) nationals as supreme organs, 3) nationals as a beneficiary of human rights, 4) nationals as subjects to be ruled. The first two explains nationals as active and power generators whilst the latter two-features nationals as passive and ruled. Art. $1 \mathrm{Cl} .2$ of Constitution proclaimed the principle of "nationals sovereignty." Nationals in this clause refer to the "people as a whole and collectively," which is idealistic rather than tangible or numerical. In this definition, nationals are tenants of a nation as sovereigns and expressly or impliedly empowered to determine the forms and foundational elements of polity as the final authority. Hence, nationals in this understanding is a unique source of national power and government.

Since nationals in the first sense are merely hypothetical or idealistic to endorse the modern form of constitutional states, the second concept arises to explicate the status of nationals in terms of constitutional engineering. Nationals as a supreme organ differ in that they are realistic to formulate the constitutional or public policy and often are incorporated within provisions as voters or electorate to participate in the organizing of government. Nationals in this class collectively refer to the "entirety of people" above a certain age and eligible to vote without any legal disqualification. The Constitution has several provisions that mention this class of nationals, i.e. 1) approval of constitutional revision on popular vote (Art. $130 \mathrm{Cl}$. 2), 2) referendum on important national policy agenda (Art. 72), 3) election of national assembly (Art. $41 \mathrm{Cl} .1$ ) and so on. The Constitution requires that every national be entitled to the basic rights of decent human dignity and the right to pursue happiness (Finnis, 2008). The government is constitutionally obliged to affirm and protect human rights bestowed naturally or inalienably (Kim, 2015). Within this purpose of constitutionalism, nationals are regarded as 
the beneficiaries of the bill of rights, which are spelled out explicitly from Art. 10 through Art. 37 of the constitution (Motomura, 1990). Nationals as an individuals are subject to be ruled, and are responsible for the performance of a public duty or legal obligation.

\section{Constitutional Order of Republic}

\subsection{Liberal and Democratic Government}

The constitution's language across the preamble and throughout its provisions clearly defines the constitutional order of the republic in terms of liberal and democratic values and principles (Buchanan, 1994). The preamble is phrased progressively to propose that the, "constitutional order on liberal democracy needs to be ensured more firmly ..." Art. 4 provides, "the government pursues a policy of peaceful reunification ..." Art. $8 \mathrm{Cl}$. 4 affords relief, "In case where the aims and activities of political party contravene the constitutional order of liberal democracy ..."

The order of this constitutional mainstream firstly appeared in Art. 18 and Art. $21 \mathrm{Cl} .2$ of the 1949 Bonn constitution. The article and clause is set forth to foreclose the disentitlement of basic human rights and mandated negation of unconstitutional parties, respectively. The concept upholds the foundational order of rule of law, and negates tyranny or arbitrary government and force and suppression while respecting the will of the majority and self-determination of nationals as sovereigns. KCC also elucidated the elements of liberal democratic government (LDG), which encompasses 1) bill of rights on human dignity and respect of person 2) popular sovereignty 3) separation of powers principle 4) accountable government 5) public administration on rule of law (=6) judicial independence 7) multiplicity of political parties and partisan liberty (Holmes, 1995).

LDG cherished within Korean constitutionalism is practically operative as; 1 ) supreme direction and normative principle preempting ordinary or lower order constitutionalism, 2) above the revision power and protected from subsequent constitutional reform, 3) provides the standard and touchstone for constitutional interpretation, 4) grounded to legitimatize governmental action or inaction and to proscribe restraints on liberty and rights, and 5) divisive line to circumscribe the inviolability of basic rights (Hopton, 1978).

Concerning the precise nature of LDG, scholars question whether it connotes or compromises with the order of constitutional democracy. Art. $1 \mathrm{Cl}$. 1 pronounces a republican form of civil democracy as an inviolable and eternal form of constitutional government in this land. The civil democracy in this phrase is literally receptive of two traditions, namely, social and liberal democracies as the scope of their meanings as catchwords are plainly understood (Huber, Ragin, \& Stephens, 1993; Kim, 2017). Neither is coherent in terms of political history, elements to advise the government, or consistency with the political culture of nations among each other. Scholars hold LDG as a principal emphasis of consti- 
tutionalism, which, however, does not rule it out in the ordering and practice of social democracies. Hence, market intervention by government is feasible as a matter of constitutional order, for the promotion of social justice and welfare, as well as beyond to a formalistic disengagement of an austere private and public sector dualism. The epistemology and rich tone that underwrites LDG, other than a social democratic government (SDG), is a guiding beacon of Korean constitutionalism as provided for in the preamble according to the explicit words previously mentioned. It needs to be distinguished within Art. $8 \mathrm{Cl}$. 4, and the LDG within this clause should be narrowly read to ordain the concept of LDG exclusive of SDG. Because the partisan clause is decisively important for freedom of political parties and the defense of democratic order-as historically shown through early German nationalism-only the core of liberal democracy can ground the lawfulness of political parties and maintain a pluralistic partisan system. This reading can bring a plausible solution since the socialistic nature of political parties-neither extremist nor totalitarian-can survive the constitutional review of a dissolution proceeding. It promotes politics of parties on diverse public causes and can be lenient on the spectrum of national politics between progressives and conservatives. In other words, LDG should be actively shielded as differs from SDG while the latter is merely feasible and granted. This understanding also mandates that any transgression of LDG shall be negated to restore the constitutional order.

Two types of constitutional tools are afforded to shield LDG, i.e., active and negative ones. The active tools are promotional and require protection of free speech and political freedom, which enables and forms the order of liberal democracy (Buchanon, 1994). The freedom of conscience, freedom of expression, press, and assembly as well as parliamentarism are predicated on the best practice of LDG. The negative tools are defensive and can be realized through a plethora of constitutional institutions, such as "judicial review of unconstitutional legislation, impeachment, advice to denounce ministers, disciplinary action of officer's misconduct, right to civil disobedience, protection within the criminal laws, national security act and administrative codes."

\subsection{The Liberal Market on Social Justice}

The nature of national economies and markets vary with the political culture and respective constitutionalism in the various global jurisdictions (Wiener, DUNOFF, HAVERCROFT, Kumm, \& Kovacs, 2019). Modern constitutions formulated around the $18^{\text {th }}$ and $19^{\text {th }}$ centuries have piously propagated civil liberties and capitalism, promoting the new ideals of a revolutionary bourgeois. The ethos and prevalence in thought had turned reflexive due to the extreme polarity of wealth, class conflict between the haves and have-nots, periodic disruption of the market, mass layoffs and so on. The crisis and challenge of these historical experiences transformed classic constitutionalism to favor a corrective mode, and governments began to intervene and control the market (Przeworski, 1986). This new kind of constitutionalism brought a sea change in terms of epistemol- 
ogy and lexicon of democratic republics as pioneered by the New Deal and the burgeoning of the administrative or positive state. The sea change had brought forth a political-arguably ramshackle-compromise in the US. Brownlie report, court packing plan and deluge of administrative laws that accounted for a new constitutionalism in the US. On the other hand, express language was employed to articulate a set of prominent articles on provision and positive liberty in the Weimar constitution, i.e., the constitution of notable civil law or pandect tradition. Given the dominant number of written constitutional states, the Weimar constitution has been cited as a paradigm of welfare or positive states by impacting on a great deal of new born republics after the Second World War.

The chapter of national economy in the Constitution endorses the sanctity of property right and principle of free market as a constitutional order (Huh, 2018; Kim, 2013; Kweon, 2010). On this principle of liberal capitalism, the constitution empowers the government to plan, intervene and control the market for social justice and public welfare, what is called economic justice within the market. Social justice and economic democratization are imbedded deeply through civil pressure groups. The current administration, traditionally viewed as leftist and progressive, now is practicing a so-called income-led economic growth, which is critiqued acrimoniously about its ill effects on viable economic growth. The social concept of market on liberal democracy may share as peered to such that social enterprises are underwritten foundationally by the chapter.

It is an economic reality that liberal democracy defines the political order of Korean constitutionalism. The discourse of the market or materialism over history has proven to be a trajectory through several stages, i.e. classic or social capitalism and planning or communist economy. The modern state as affected by a high rate of industrialization became aware of the need to rethink ideals and courses of action by facing the evils and failure of a laissez-faire economy (Petersmann, 2000). The social market economy, in the end, is an economic constitutional order for the nation and supports a mixed nature of macro-economic practice. An inviolable element is said to underlie inherently within the mandates of this chapter, such as the effect of economic order on human dignity and individual freedom. Therefore, any negation of private property conditioned to the practice of totalitarian or communist economies contravened the Constitution and is deemed unconstitutional. This chapter, hence, works to explicate the proscription and limits of governmental intervention within the market.

\subsection{International Peace and Respect for International Law}

Upon reflection on the atrocities and disorder from two world wars, global states began to promulgate constitutions that respond to the international cause for peace and the prevention of force (De Wet, 2006). In this vein, the Constitution sets forth several principled articles to 1) idealize and direct the peaceful reunification of the two divided Koreas (Preamble, Art. 4, Art. 66 Cl. 3, Art. 69) 2) un-constitutionalize and outlaw the wars of aggression (Art. 5, Cl. 1) 3) respect the international law and due process of law for aliens (Art. 6). 
In response with the increasing codification of international peace regime and security protocols across the global jurisdictions, the Constitution disapproves and outlaws wars of aggression and declares a call for international peace within the preamble "advocating the eternal peace of world and prosperity as a premier goal of foreign affairs in the nation." On this constitutional principle, however, a war of defense or sanction is constitutionally permissible although a war of conquest or recourse to settle international disputes is denied. A war of defense is viewed to provide security and protect nationals and Korean territories against imminent or illegal aggression from foreign nations. A war of this nature is also permitted through the relevant provision of UN Charter. The war of sanction is a legal and internationally customized recourse when the $\mathrm{UN}$, as the resident power of an international policing function, organizes the necessary military force to sanction armed aggression, as well as to ensure international peace and security.

As the international order generally is created through international law and treaty agreement, respect and faithful implementation of national obligations arising from extraterritorial ones are pivotal to sustain them. Art. $6 \mathrm{Cl}$. 1 within the Constitution explicitly pronounces respect for the international order by declaring that "the international laws customized through various states and treaty agreement concluded in accordance with the Constitution shall have a same effect and status to domestic laws." A treaty agreement as the term is used in this clause refers to any agreement or contract of written form entered into by relevant states. Nevertheless, an international organization, for example UN, can also be a contracting or membership party along with states, which means that a treaty can be entered among states or international organizations or a combination of the two. The Constitution offers two treaty provisions dealing with procedural requirements. Art. 73 concerns the treaty power of the president by authorizing him or her to conclude and ratify it. Art. $60 \mathrm{Cl} .4$ expressly vests the power of ultimate assent within the national assembly. International law customized through various states may cohere with two main sources of objective international law, namely, multinational treaties of a legal character and international customary law. Some articles of UN Charter, The Third Geneva Convention Relative to the Prisoners of War, Convention on the Prevention and $\mathrm{Pu}$ nishment of the Crime of Genocide, Treaty for the Renunciation of the War would fall within the first class while the Convention against the Massacre and Inhumane Treatment of War Prisoners, Principles on the Status of Ambassadors and Ministers, Principle on Self-determination, Pacta Sund Servanda can be grouped into the second category.

Art $6 \mathrm{Cl} .2$ ensures a protection for the aliens on the principle of comity, "aliens are entitled to the protection of laws as accorded with the international laws and treaty." Peaceful reunification is an ultimate goal of Constitution. The Constitution provides a number of articles to promote the national goals of reunification through peaceful means and diplomacy. They reside partly in the preamble, declaration of peaceful reunification on Art. 4, constitutional mandate on presidency concerning Art. $66 \mathrm{Cl} .3$, presidential oath on Art. 69, and the Ad- 
visory Council on Democracy and Reunification.

\section{Constitutional Institutions}

\subsection{Partisan Clause}

The partisan state developed as an upgrading of democracy led by professional politicians or political parties and is now popularly and deemed necessary to address the politics and constitutionalism of the specific nations (Pildes, 2005; Riker, 1982; Sunstein, 1993). This development facilitated the constitutionally instituted party system where political parties exercise a practically major influence to create the national policy and lead the legislative agenda. In order to increase the role of political parties and their constitutional status within contemporary nations, the liberty of political parties to form and act should be safeguarded in order for the full-scale effect and plurality of political freedom to be completely established. The Act on Political Party, Art. 2 defines that the political party as a matter of this statutory purpose indicates a voluntary association of people with the aims: 1) to pursue the political ideals and public policies to their interest 2) to formulate their political wills or preferences by supporting or nominating a candidate for numerous public elections. Constitutionally permissible parties are required to 1 ) accept the legitimacy of the nation and liberal democracy 2) make effort to advance the public ideals 3) participate in the public election process 4) publicize partisan ethics and policies 5) be actively engaged to formulate the political will or preference of people 6) maintain a well-organized and continuous association 7) and have members eligible as a matter of the requirements of partisan membership.

Provided that popular democracy at the present times crucially relies on partisan politics to secure political freedom and activities, liberty of political parties and the plural system constitute one of the core elements within a liberal democracy. With this point of view, Art. $8 \mathrm{Cl} .1$ of the Constitution sets forth that, "institution of political parties should not be abridged and the plural system is constitutionally guaranteed." Political parties are entitled to nominate referees for respective voting places and ballots. According to Art. $8 \mathrm{Cl} .2$, the mass party's purpose, organization and activities should be democratic with a national distribution or a number of local branch needs sufficient to fully formulate the political will and preferences of people. Art. $8 \mathrm{Cl}$. 2 is important to defend the legitimacy of the nation and democratic constitutionalism, and proscribes unlawful purposes and activities of political parties against the foundational order of liberal democracy or that menace the establishment of the nation. The Constitution, on the other hand, also protects and promotes the political parties according to the acts or statutes, authorizing political parties to be funded to operate their cause and function within Art. 8 Cl.3. In advancing the constitutional mandate, the Act on Political Funding has been adopted (Fleishman, 1973). It purports is to 1) provide adequate financing to a reasonable standard and 2) requires publicly disclosure of party financial accounts and statements in order to avoid black politics or inner-party cronyism. 


\subsection{Public Election as a Constitutional Institution}

In the history of politics in democratic and republican nations, public elections have played a crucial role in support of modern constitutionalism whether the system or government was parliamentary or presidential. Within the realm of popular sovereignty, the rationale and service of public elections underlie its benefits from the politics of compromise and consent and the duly-elected representatives of the people. Nevertheless, the character and meaning of public elections has transformed to a great extent in the partisan state. In partisan democracy, the public election no longer gravitates on the individual representative, but is transformed to a focus on selecting the best government among two or three alternatives on a partisan basis. The evolution of public elections in this sense resembles the role of the plebiscite in the classic discourse.

The following describes the principles of public elections ideated and upheld through Korean constitutionalism (Huh, 2018; Kim, 2013; Kweon, 2010). We have noted five principles including the 1) election by a universal franchise, 2) election based on the equal right to vote, 3) direct election, 4) confidential election, and 5) free election. The universal franchise is an antonym of a restrictive franchise allowing a person of certain age to vote regardless of his or her social status, race, religious beliefs and education. It generally corroborates the requirements of modern democracy. Equal election proscribes a public election on a discriminatory basis and requires the respective vote of every election participant to be given equal weight. The principle of equal election also requires "quality equal protection" beyond one vote one count. In other words, it derogates the arbitrary partitioning of the electorate, so-called gerrymandering, which arises as a constitutional issue debated in the national courts. The Korean Constitutional Court (KCC) had delivered several cases on past gerrymandering. Confidential election protects a voter from unwished or harmful disclosure of his voting choice. It can be practiced with the anonymity of voting paper. The free election also came to forestall compulsory elections, which requires the voters to be free from external or internal interventions and pressure.

The electoral system refers to partitioning of electoral unit, including small, medium and large-scale units. The small-scale system is designed to elect one representative in each unit. The medium-scale system generally yields two or five elects in each unit while the large-scale system is widest in partitioning for each electorate.

\subsection{Public Officer as a Constitutional Institution}

Public officers may be institutions created by the constitution, which refers to the scope of persons who are elected directly or indirectly through public election and responsible for public administration or execution of laws within the national or local government and law-creating public organizations. The power to appoint to a public office generally vests within the Presidency except for elected offices (Art. 78). The public officers are classed into 1) national and local 
officers and 2) career and special career officers. Nevertheless, the classification may be obviated by statutes that are enacted form time-to-time, which involves substrate issues that are lower than the constitution (Ziegler Jr., 1979). The constitution also provides an independent set of concepts and classifications.

Art. $7 \mathrm{Cl}$. 1 pronounces that, "the public officer serves people and is responsible for them," which is deemed a principled clause to govern the respective duties of public officers within the statutory framework. The clause reaffirms democratic republicanism within the Constitution (Art.1), which underlies popular sovereignty.

Within the notion of popular sovereignty, the people are sovereign and function in lieu of or equivalent to feudal monarchy so that the public officers are responsible for serving the best interests of the people in a collective sense. It requires that he or she should not be partisan to serve a factional interest relating with an individual, political party, social class, religion or province. In particular, the loyalty of public officers spelled out by constitution entails a special significance commanding that the people wholly are the ultimate beneficiaries of the services of a public official, and not the ruler or ruling party. When public officers are empowered to execute laws and programs by the sovereign people, they should not serve as a private army of the ruling government.

The responsibility of public officer as stated in a late paragraph, Art. $1 \mathrm{Cl} 1$ of Constitution functions in three categories, including, 1) the responsibility as a server for people, 2) to represent the national ideals, and 3) discharge their official power according to the law. Since the Constitution does not provide a general dismissal clause for public officers, the responsibility needs to be interpreted as an ideal or political projection. Nevertheless, an explicit provision is not absent, and we see in Art. 29 of Constitution that the responsibility is legal with a practical consequence. This method of determining the responsibility of public officers is versatile to cover reelection, impeachment, advice and recommendation to dismiss, petition to dismiss and damages claims.

Art. $7 \mathrm{Cl} .2$ in the Constitution provides that the status and political neutrality of public officers shall be ensured according to the law, which is meant to establish a seniority system as a principle (Huh, 2018; Kim, 2013; Kweon, 2010). The system has evolved to overcome the defunct older regime of cronyism within the modern governmental history. The seniority system enjoyed by life career public officers needs to be legitimate and scientific in order to increases the effectiveness of governmental operations and maintain their independence from the ruling party. To this end, the following is necessary and required, 1) assurance of a scientific promotion ladder and classification that corresponds with the nature and responsibility of the job, 2) unauthoritative or democratic management of appointments and dismissals, 3) a fixed promotion and tenure system, 4) result-based rewards and disciplinary actions favoring independence and enhancing the abilities of officers, as well as 5) neutral and autonomous administrative units of personnel management. 


\subsection{Local Government System}

The autonomy of local government is required to directly promote grassroot democracy and pluralism by formulating and organizing the will of the local peoples as authorized by national politics and central government (Briffault, 1996). Local government can prevent the malfeasance of national government due to excessive centralization and possibly extravagant bureaucracy. It enables checks and balances on the abuse of governmental power and ensures the liberty interest of people through a vertical separation of powers. On the other hand, local government can also enhance the public welfare or paradigm of the social state in collaboration with the central government according to the division of labor principle (Bardhan \& Mookherjee, 2006).

The Constitution has a chapter of local government in the Eighth and two articles that mandate a constitutional guarantee for the local autonomy and basic policy direction concerning the central-local system (Huh, 2018; Kim, 2013; Kweon, 2010).

First, Art $117 \mathrm{Cl} .1$ explicitly declares a wide latitude for local governments, stating that, "the local government is responsible for the public welfare of residents or management of their assets and able to create the local laws or regulations within the permissible scope as pertains to national laws." The clause is designed to affirm a wide latitude of autonomous administration on behalf of the local government. Cl. 2 includes the constitutional affirmation and respect of local autonomy by stipulating that the types of local government will accord with the law enacted by the national assembly.

Second, Art. $118 \mathrm{Cl} .1$ provides that the local congress will be elected within the respective government. $\mathrm{Cl} .2$ in the same article articulates that the statute will specify the organizing, responsibility and election requirements for a local congress and head of government as well as other details of organizing or operating the local government. The article was intended to ensure a democratic process of local governance by making explicit the methods of organizing the congress and head of government.

\section{Reflexivity}

Constitutional law is the supreme law of land within democratic jurisdictions. The law, therefore, functions to police other sorts of national or state laws-the kind of intrigues and smorgasbord of other methods used for state engineering-with several traditional forms of judicial review. Abstract review, concrete review and preliminary review plus post-enactment review will provide the integrity and foundation of nations for the protection, stability, predictability and progress of the state and its people. For example, a statute that is repugnant to the Constitution is deemed null and void as a matter ab initio or voided if it could not be applied as a valid law in the case under review. In some cases, a draft statute, if found unconstitutionally by the board of preliminary review, is recommended to be dropped and fails to maturate as a new law. The conse- 
quence is that the Constitution is most central to understanding of the specifics of statecraft, public administration as well as the nature of preventing political strife through humanity and positive social relations.

Constitutional law may be written or unwritten in terms of its forms and practice. The written forms of constitution are originated from the US tradition while unwritten constitutions have their basis in the constitutional practice of the United Kingdom. Other variances can be found in communist nations and theocracies, whose understanding of constitution is of ancillary nature as subjugated by the dictating labor parties or charismatic religious leadership in the nation. The constitution is nothing but a hyper-state of bourgeois relations in terms of production in a Marxian viewpoint while the liberal paradigm generally accepts the social contract between a monarch-as flowing from sovereignty of the people-and the monarch's subjects. Partly sympathetic with the Marxian view is a group of scholars that raise a plutocracy argument that the Constitution of United States was invented to protect a new class of commercial wealth through various institutions. In other words, their hindsight on the creation of the constitutional system commands a cardinal emphasis on government through check and balances-within the separation of powers principle-or bicameralism as well as the federal system (Kim, 2014). They believe that weaker government based on this new social contract would ensure their interest in life, liberty and property.

The constitution for the Korean republic also has been the supreme law of land as a matter of constitutional principle and practice. It is a written form of constitution and revised nine times since the constitution of first republic was enacted in 1948. The Constitution largely underwrites the presidential system of government except for that of second republic, whose duration was as short as one year. Its creation was contended enthusiastically between the right and left parties within and around the independence period between 1945-1948. It was so although a limited elite group could only comprehend earlier concepts of class consciousness, exploitation and economic injustice from the evils of excessive capitalism. The nature of a new property right and a broadened national economic focus along with the government was argued by so-called Korean founding fathers (for example, Jin-oh Yoo as a constitutional drafter and Seung-man Lee as a national leadership), and an enlarged scope of state intervention into economy matters was subscribed into the chapters and provisions of the constitution. Nevertheless, the provisions on political institutions and judiciary looked to ensure the paradigm of liberal constitutionalism. The current constitution also has the Chapter of National Economy as distinguished from the U.S. precedent, which does not deny liberal capitalism as a major constitutional goal that, however, could be complicated by and with state intervention. The followings are a gist of summary presented in this paper.

- The concept of a constitution has a dual facet of normativity or jurisprudence and social or political manifestation within a polity. 
- The constitution transforms over time, and we can identify three projections, i.e., original use of the constitution, and modern and contemporary constitutionalism.

- Categories and classifications are pluralistic as a matter of constitutional existentialism.

- The founding and revision or amendment of constitution has historically occurred and is being ideologically debated with respect to its nature and limitations.

- The defense on Korean constitutionalism was spelled out within the Constitution.

- The constitutional status of nationals is principled and is mandated according to law.

- The profound order of Korean constitutionalism appears in the general chapter of Constitution.

The profound institutions of Korean constitutionalism are profiled over its chapters and provisions.

\section{Conflicts of Interest}

The authors declare no conflicts of interest regarding the publication of this paper.

\section{References}

Arendt, H. (1972). Crises of the Republic: Lying in Politics, Civil Disobedience on Violence, Thoughts on Politics, and Revolution (Vol. 219). Boston, MA: Houghton Mifflin Harcourt.

Balakrishnan, G., \& Schmitt, C. (2000). The Enemy: An Intellectual Portrait of Carl Schmitt. Brooklyn, NY: Verso.

Barak-Erez, D. (2008). Israel: Citizenship and Immigration Law in the Vise of Security, Nationality, and Human Rights. International Journal of Constitutional Law, 6, 184. https://doi.org/10.1093/icon/mom036

Bardhan, P., \& Mookherjee, D. (2006). Decentralization and Local Governance in Developing Countries: A Comparative Perspective (Vol. 1). Cambridge, MA: The MIT Press. https://doi.org/10.7551/mitpress/2297.001.0001

Barendt, E. M. (1998). An Introduction to Constitutional Law (Vol. 4). Oxford: Oxford University Press.

Bellah, R. N. (1978). Religion and Legitimation in the American Republic. Society, 15, 16-23. https://doi.org/10.1007/BF02694707

Borowski, M. (2003). The Beginnings of Germany's Federal Constitutional Court. Ratio Juris, 16, 155-186. https://doi.org/10.1111/1467-9337.00230

Briffault, R. (1996). Local Government and the New York State Constitution. In Hofstra Law and Policy Symposium (Vol. 1, p. 79).

Buchanan, J. M. (1994). Notes on the Liberal Constitution. Cato Journal, 14, 1.

Caenegem, R. C. C., Van Caenegem, R. C., \& Johnston, D. (1995). An Historical Introduction to Western Constitutional Law. Cambridge: Cambridge University Press. 
https://doi.org/10.1017/CBO9781139170871

Caldwell, P. C. (1997). Popular Sovereignty and the Crisis of German Constitutional Law: The Theory \& Practice of Weimar Constitutionalism. Duke, NC: Duke University Press. https://doi.org/10.1215/9780822397656

Cepeda, M. J. (1998). Democracy, State and Society in the 1991 Constitution: The Role of the Constitutional Court. In Colombia (pp. 71-95). London: Palgrave Macmillan. https://doi.org/10.1007/978-1-349-26050-8 4

De Wet, E. (2006). The International Constitutional Order. International \& Comparative Law Quarterly, 55, 51-76. https://doi.org/10.1093/iclq/lei067

Eidsmoe, J. (1987). Christianity and the Constitution: The Faith of Our Founding Fathers. Grand Rapids, MI: Baker Book House.

Engel, C. (2001). Hybrid Governance across National Jurisdictions as a Challenge to Constitutional Law. European Business Organization Law Review, 2, 569-583. https://doi.org/10.1017/S1566752900000604

Finnis, J. (2008). Nationality, Alienage and Constitutional Principle.

Fleishman, J. L. (1973). Public Financing of Election Campaigns: Constitutional Constraints on Steps toward Equality of Political Influence of Citizens. North Carolina Law Review, 52, 349.

Foucault, M., Faubion, J. D., \& Hurley, R. (1998). Aesthetics, Method, and Epistemology (Vol. 2, pp. 369-391). New York: New Press.

Glendon, M. A. (1997). Knowing the Universal Declaration of Human Rights. Notre Dame Law Review, 73, 1153.

Gozzi, G. (2007). Rechtsstaat and Individual Rights in German Constitutional History. In The Rule of Law History, Theory and Criticism (pp. 237-259). Dordrecht: Springer. https://doi.org/10.1007/978-1-4020-5745-8 5

Graves, W. B. (1960). Current Trends in State Constitutional Revision. Nebraska Law Review, $40,560$.

Habermas, J. (2007). A Political Constitution for the Pluralist World Society? The Journal of Chinese Philosophy, 34, 331-343. https://doi.org/10.1111/j.1540-6253.2007.00421.x

Hartmann, B. J. (2003). The Arrival of Judicial Review in Germany under the Weimar Constitution of 1919. Brigham Young University Journal of Public Law, 18, 107.

Holmes, S. (1995). Passions and Constraint: On the Theory of Liberal Democracy. Chicago, IL: University of Chicago Press.

Hopton, T. C. (1978). Grundnorm and Constitution: The Legitimacy of Politics. McGill Law Journal, 24, 72.

Huber, E., Ragin, C., \& Stephens, J. D. (1993). Social Democracy, Christian Democracy, Constitutional Structure, and the Welfare State. American Journal of Sociology, 99, 711-749. https://doi.org/10.1086/230321

Huh, Y. (2018). The Textbook of Korean Constitution. Seoul: Pagyŏngsa.

Kim, C. S. (2013). The Treatise on Korean Constitution. Seoul: Pagyŏngsa.

Kim, H. (1992). The Influence of the American Constitution on South Korean Constitutional Development since 1948. Asian Perspective, 16, 25-42.

Kim, K. (2014). Human Rights: Are They Just a Tweak for the Policy Makers or Administrators? European Academic Research, 2, 7760-7783.

https://ssrn.com/abstract=2572951

Kim, K. (2014). The Constitution and Tripartite System of Government: From the Mutiny for the Limited Government through the Interbranch Subtlety. International Jour- 
nal of Advanced Research, 2, 392-401. https://ssrn.com/abstract=2574711

Kim, K. (2017). Rethinking the Relationship between the Constitutional Tradition and Democracy: Democratic Experimentalism and Candlelight Vigil in South Korea. Chosun Law Journal, 24, 101-139. https://ssrn.com/abstract=3096413 https://doi.org/10.18189/isicu.2017.24.3.101

Kweon, Y. S. (2010). The Introduction to Korean Constitution. Seoul: Bupmunsa.

LaCroix, A. L. (2015). The Interbellum Constitution: Federalism in the Long Founding Moment. Stanford Law Review, 67, 397.

Lassale, F. (1987). O que é uma Constituição Política Global.

Lowenstein, K. (1976). Teoría de la Constitución. Barcelona: Ariel.

Motomura, H. (1990). Immigration Law after a Century of Plenary Power: Phantom Constitutional Norms and Statutory Interpretation. Yale Law Journal, 100, 545-613. https://doi.org/10.2307/796662

Petersmann, E. U. (2000). The WTO Constitution and Human Rights. Journal of International Economic Law, 3, 19-25. https://doi.org/10.1093/jiel/3.1.19

Pildes, R. H. (2005). The Constitution and Political Competition. Nova Law Review, 30, 253.

Pomeroy, J. N. (1888). An Introduction to the Constitutional Law of the United States: Especially Designed for Students, General and Professional. Mifflin, PA: Houghton.

Przeworski, A. (1986). Capitalism and Social Democracy. Cambridge: Cambridge University Press. https://doi.org/10.1017/CBO9781139171830

Ray, C. H. (2019). John Marshall’s Constitutionalism. Albany, NY: SUNY Press.

Reus-Smit, C. (2001). Human Rights and the Social Construction of Sovereignty. Review of International Studies, 27, 519-538. https://doi.org/10.1017/S0260210501005198

Reynolds, A. (2002). The Architecture of Democracy: Constitutional Design, Conflict Management, and Democracy. Oxford: OUP.

Riker, W. H. (1982). The Two-Party System and Duverger's Law: An Essay on the History of Political Science. American Political Science Review, 76, 753-766. https://doi.org/10.1017/S0003055400189580

Rosas, A., \& Armati, L. (2018). EU Constitutional Law: An Introduction. London: Bloomsbury Publishing.

Rossiter, C. (2017). Constitutional Dictatorship: Crisis Government in the Modern Democracies. Abingdon-on-Thames: Routledge. https://doi.org/10.4324/9781315080536

Selby, J. E. (1976). Richard Henry Lee, John Adams, and the Virginia Constitution of 1776. The Virginia Magazine of History and Biography, 84, 387-400.

Smend, R. (1928). Verfassung und verfassungsrecht. Berlin: Duncker \& Humblot.

Sunstein, C. R. (1993). The Partial Constitution. Cambridge, MA: Harvard University Press. https://doi.org/10.2307/1341781

White, R. T. (1951). Amendment and Revision of State Constitutions. University of Pennsylvania Law Review, 100, 1132. https://doi.org/10.2307/3310069

Wiener, A., Dunoff, J. L., Havercroft, J., Kumm, M., \& Kovacs, K. (2019). Global Constitutionalism as Agora: Interdisciplinary Encounters, Cultural Recognition and Global Diversity. Global Constitutionalism, 8, 1-11. https://doi.org/10.1017/S2045381719000030

Ziegler Jr., E. H. (1979). Government Speech and the Constitution: The Limits of Official Partisanship. Boston College Law Review, 21, 578. 